\title{
Synthesis of $\mathrm{SrFe}_{12} \mathrm{O}_{19}$ by sol-gel method and its morphology and magnetic properties
}

- Le Anh Bao Quynh

- Nguyen Hoang Vu

- Tran Thi Thuy Hoang

- Huynh Ky Phuong Ha

Ho Chi Minh city University of Technology, VNU-HCM

(Manuscript Received on July, 2016, Manuscript Revised on September, 2016)

\section{ABSTRACT}

In this research, strontium hexa-ferrite hexagonal crystal structure for powders which nanoparticles (SrFe12O19) were synthesized by sol-gel method. The crystal structure, morphology and magnetic properties of nanoparticles were investigated using $X$-ray Diffraction (XRD), Scanning Electron Microscope (SEM) and Vibrating Sample Magnetometer (VSM). The XRD patterns confirmed the formation of single phase M-type was calcined above $7000 \mathrm{C}$. The product shows the magnetization of $66 \mathrm{emu} / \mathrm{g}$, which is consistent with pure hexa-ferrite obtained by other methods, and the magnetic coercivity of 6,145 kOe higher than expected for this hexaferrite. The powder morphology is composed of aggregates of hexagonal particles with an average particles size of above 100nm.

Keywords: Strontium hexa-ferrite, sol-gel method, magnetic material.

\section{INTRODUCTION}

M-type hexagonal ferrites are important permanent magnetic materials which was widely studied since their discovery in the 1950s [1]. As a kind of hard magnetic material, the hexagonal ferrite material efficiency has the chemical formula of MFe12O19 ( $\mathrm{M}=\mathrm{Ba}, \mathrm{Sr}$, $\mathrm{Pb})$. Due to the magnetic properties and cost efficiency, hexa-ferrites was considered as a material with promising scientific and technological applications such as permanent magnets, electrical and microwave devices, data storage and recording, plastoferrites [1,2], RAM and microwave/EM wave absorption, magnetoelectric (ME) and multiferroic (MF) application and a multitude of other applications [1].

The formation of M-type hexagonal ferrites is an extremely complicated process, and the mechanisms involved are not fully understood 
despite having been investigated by many researchers for over 50 years [1]. Various synthesis methods of M-type hexagonal ferrites were developed, including standard ceramic techniques [1,3], co-precipitation [4,5], ion exchange [6], sol-gel method [7], citrate synthesis [1,8], hydrothermal synthesis [9], glass crystallization [1,10], the combustion method [11,12], self-propagating high temperature synthesis (SHS) [1,13], spray drying [1], waterin-oil micro-emulsions [1,14] and industrial manufacture of hexagonal ferrites $[1,15]$.

$\mathrm{SrFe}_{12} \mathrm{O}_{19}$ is a hard magnetic material due to its high coercivity. $\mathrm{SrFe}_{12} \mathrm{O}_{19}$ plays a relatively special role due to its appropriate magnetic properties, chemical stability, corrosion resistivity and cost efficiency in comparison with rare-earth compounds $[1,15]$.

The sol-gel method has been already established as an alternative route for magnetic ferrite synthesis. This method allows the preparation of $\mathrm{SrFe}_{12} \mathrm{O}_{19}$ with high crystalline perfection and small particle sizes, resulting in the favorable properties for several technological applications [15].

Therefore, in this paper, strontium hexaferrite nanoparticles were synthesized with the $\mathrm{Fe} / \mathrm{Sr}$ ratio of $12 / 1$ by sol-gel method prior to the study regarding the effect of annealing temperature on phase formation, microstructure and magnetic properties of strontium hexaferrite nano powders.

\section{EXPERIMENTAL}

\subsection{Materials}

Iron (III) nitrate nonahydrate (Fe(NO3)3.9H2O ( $\geq 98 \%)$ and strontium nitrate $(\mathrm{Sr}(\mathrm{NO} 3) 2)(\geq 99 \%)$ were used as inorganic reactants, while ethylenediamine tetraacetic acid (EDTA) (99\%) was used as chelating agent, ammonium hydroxide (25 wt.\%) and distilled water were used to prepare strontium hexaferrite nanoparticles. All starting precursors were of high purity compounds and were purchased from Xilong Chemical (China).

\subsection{Preparation by sol-gel method}

The starting precursors $\left(\mathrm{Fe}\left(\mathrm{NO}_{3}\right)_{3} \cdot 9 \mathrm{H}_{2} \mathrm{O}\right.$, $\left.\mathrm{Sr}\left(\mathrm{NO}_{3}\right)_{2} ; \mathrm{Fe} / \mathrm{Sr}=1 / 2\right)$ with a stoichiometric amount of metal nitrates were dissolved in deionized water under continuous stirring. The sols were prepared by dissolving the metal salts and ethylene diamine tetra acetic acid at which the molar ratio of EDTA to total metal cations were 1:1. Subsequently, ethylene glycol was added to the solution while the ratio of $\mathrm{Fe} 3+$ to ethylene glycol was 1:1 in moles of pure substance. $\mathrm{pH}$ of the solution was also adjusted to $7 \pm 0.5$ using ammonia under continuous stirring. The temperature of $\mathrm{Fe}-\mathrm{Sr}$ precursor solution was maintained at $80^{\circ} \mathrm{C}$ to obtain the desired viscosity. In the next step, drying the obtained gel at $150^{\circ} \mathrm{C}$ from 2 to 4 hours sufficiently dehydrated the product. Finally, the product was annealed at different temperatures $\left(700,800,900\right.$ and $\left.1000^{\circ} \mathrm{C}\right)$ for $2 \mathrm{~h}$.

\subsection{Characterizations}

The X-ray Diffraction (XRD) patterns of powders that prepared at various annealing temperatures were recorded by the D8 Advance Bruker system using $\mathrm{Cu}-\mathrm{K} \alpha$ radiation $(\lambda=$ $0.154056 \mathrm{~nm}$ ) with $2 \theta$ ranging from 20 to 80 o. Scanning Electron Microscopy (SEM) images were obtained using the Hitachi S-4800 which is operated at 0.5 - 30kV. A Vibrating Sample Magnetometer (VSM, Microsense EV11) was

\section{Trang 6}


used to measure the magnetic properties at room temperature.

\section{RESULTS AND DISCUSSION}

Basing on $\left(\mathrm{Fe}\left(\mathrm{NO}_{3}\right)_{3} .9 \mathrm{H}_{2} \mathrm{O}, \quad \mathrm{Sr}\left(\mathrm{NO}_{3}\right)_{2}\right.$, EDTA, EG; $\mathrm{SrFe}_{12} \mathrm{O}_{19}$ was synthesized by solgel method. The gel was treated at different temperature from 700 to $1000^{\circ} \mathrm{C}, 2$ hours in the air.

\subsection{XRD analysis}

Figure 1 presents the XRD patterns of $\mathrm{SrFe} 12 \mathrm{O} 19$ calcined powders at temperatures from 700 to $1000^{\circ} \mathrm{C}$. As can be seen, the distinct peaks in both XRD patterns appeared at 32.35, $34.18,37.12,40.38,56.85$ and $63.13^{\circ}$ attributed to (107), (114), (203), (205), (2011) and (220) reflections for the standard pattern of M-type hexagonal SrFe12O19 crystals (JCPDS card no. 33-1340) [15]. Furthermore, as the annealing temperature increases (from 700 to $1000^{\circ} \mathrm{C}$ ), the intensity of peaks, specially, that at $2 \theta=34.18$ (114), is found to increase suggesting the improvement in the degree of crystallinity of the annealed powders at further temperate.

On the other hand, annealing at $700^{\circ} \mathrm{C}$ was not sufficient to obtain the single phase of hexagonal crystal structure. The characteristic peaks appeared completely when the sample was annealed at $900^{\circ} \mathrm{C} 2$ hours at which the crystallinity was enhanced to form single phase $\mathrm{SrFe}_{12} \mathrm{O}_{19}$.

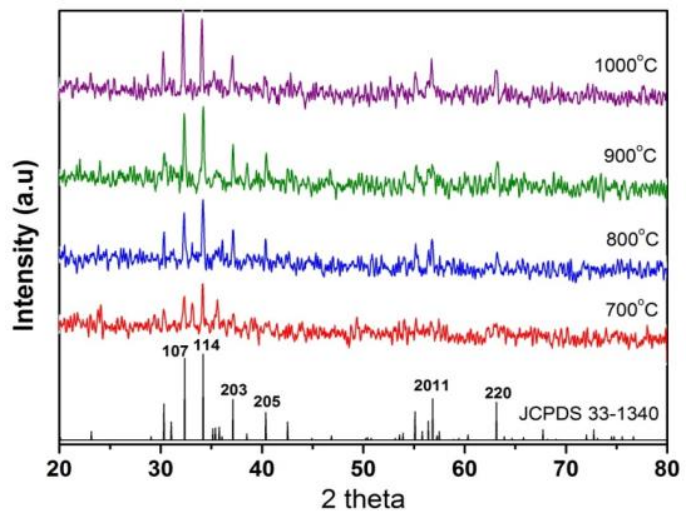

Figure 1. XRD patterns for $\mathrm{SrFe}_{12} \mathrm{O}_{19}$ powders for 2 hours in air

\subsection{SEM results}

Figure 2 presents SEM images of the prepared samples with EDTA at $900 \mathrm{oC}$. It can be observed that most of the particles share hexagonal shape and the average particlesis in the proximity of $100 \mathrm{~nm}$. That results are also observed with sol-gel process [16].
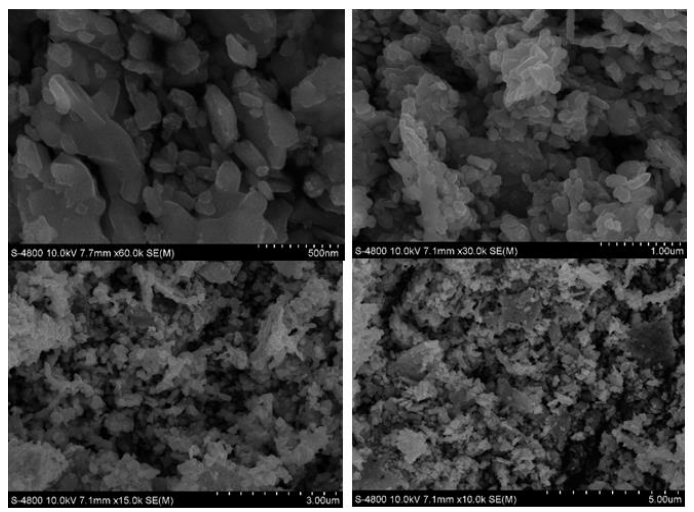

Figure 2. $\mathrm{SEM}$ images of $\mathrm{SrFe}_{12} \mathrm{O}_{19}$ powders annealed at $900^{\circ} \mathrm{C}$ for 2 hours in air

\subsection{VSM results}

Magnetization curves of the $\mathrm{SrFe}_{12} \mathrm{O}_{19}$ powders which was calcined at $900^{\circ} \mathrm{C}$ for 2 hours is shown in Figure 3. The specific saturation (Ms) and coercivity $(\mathrm{Hc})$ of sample are also obtained from VSM measurement. The 
specific saturation magnetization of synthesized $\mathrm{SrFe}_{12} \mathrm{O}_{19}$ is about $69.50 \mathrm{emu} / \mathrm{g}$. The intrinsic coercivity of the sample is about 5696 Oe and it exhibits characteristics of single magnetic domains $(\mathrm{Mr} / \mathrm{Ms}=0.56)$, confirming the isotropic characteristic of this sample that makes $\mathrm{SrFe}_{12} \mathrm{O}_{19}$ a promising candidate for various applications.

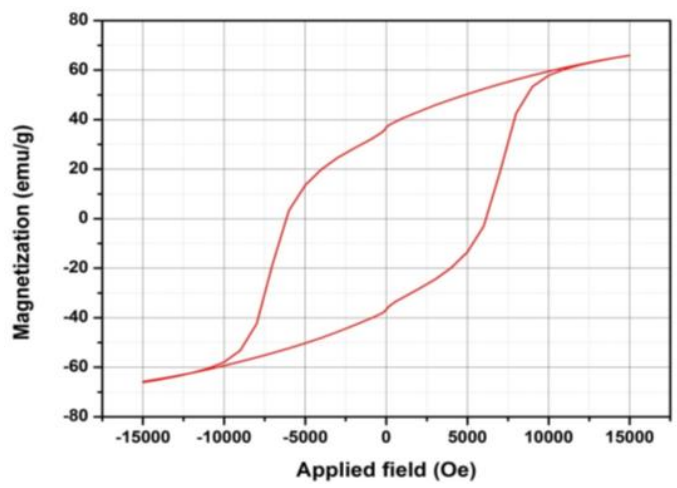

Figure 3. Magnetization curves of the $\mathrm{SrFe}_{12} \mathrm{O}_{19}$ powders annealed at $900^{\circ} \mathrm{C}$ for 2 hours

\section{CONCLUSIONS}

In this paper, the effect of calcination temperature $\left(\mathrm{T}=700-1000^{\circ} \mathrm{C}\right)$ on structural, morphological and magnetic properties of $\mathrm{SrFr}_{12} \mathrm{O}_{19}$ nanoparticles which was prepared by sol-gel method have been studied in details. Although the formation of the crystal starts at $700 \mathrm{oC}$, highly-structured single crystalline strontium hexa-ferrite phase was sufficiently formed at $900^{\circ} \mathrm{C}$ as proved by XRD results.

The SEM images of the produced ferrite present a low agglomeration rate of particles as well as the particle sizes in the proximity of 100 nm.

From the magnetization curves of the $\mathrm{SrFe}_{12} \mathrm{O}_{19}$ powders which calcined at $900^{\circ} \mathrm{C}$, the specific saturation magnetization of $69.50 \mathrm{emu} / \mathrm{g}$ along with the instrinsic coercivity of 5696 Oe are identified.

\section{Trang 8}




\section{Tổng hợp $\mathrm{SrFe}_{12} \mathrm{O}_{19}$ bằng phương pháp sol-gel và kết quả hình thái và tính chất từ tính của vật liệu.}

- Lê Anh Bảo Quỳnh

- Nguyễn Hoàng Vủ

- Trần Thị Thúy Hoàng

- Huỳnh Kỳ Phương Hạ

Trường Đại học Bách Khoa, ĐHQG-HCM

\section{TÓM TÁT}

Trong phạm vi nghiên cứu này, các hạt nano hexa-ferrite (SrFe12O19) đã được tổng hợp bằng phuoong pháp sol-gel. Cấu trúc tinh thể, hình thái được phân tích bằng các phép đo Nhiễu xa tia X (XRD), Kính hiến vi quét (SEM) và tính chất tù̀ tính của các hạt nano được do bằng Tù kế mẫu rung (VSM). Các kết quả phổ XRD cho thấy việc hình thành đon pha cấu trúc

tính thể loại $M$ dạng lụ giác khi mẫu nung ở nhiệt độ trên $700^{\circ} \mathrm{C} 2$ giờ trong không khí. Mẫu cho kết quả độ tù hóa là $66 \mathrm{emu/g}$, phù hơp với các phuoong pháp nghiên cứu về hexa-ferrite tinh khiết. Lực kháng tù là 6,145 kOe cao hơn so với các kết quả tù các nghiên cứu trước đó về hexa-ferrite. Hình thái của các hạt nano lục giác có kích thước trung bình khoảng 100nm.

Tù khóa: Strotium hexa-ferit, phurong pháp sol-gel, vật liệu tù tính.

\section{REFERENCES}

[1]. R.C. Pullar, Hexagonal ferrites: A review of the synthesis, properties and applications of hexaferrite ceramics, Progress in Materials Science 57, 11911334, (2012).

[2]. S.H. In, Ferromagnetic materials, Amsterdam: North-Holland Physics Publishing 3, (1982).

[3]. Q. Mohsen, Factors Affecting the Synthesis and Formation of Single-Phase Barium Hexaferrite by a Technique of Oxalate precursor, American Journal of Applied Sciences 7, 914-921, (2010).

[4]. Drofenik, D.L.a.M., The Low-Temperature Formation of Barium Hexaferrites, Journal of the European Ceramic Society 26, 36813686, (2006).

[5]. Z.F. Zi, Y.P.S., X.B. Zhu, Z.R. Yang, J.M. Dai, W.H. Song, Structural and magnetic properties of $\mathrm{SrFe}_{12} \mathrm{O}_{19}$ hexaferrite synthesized by a modified chemical coprecipitation method, Journal of 
Magnetism and Magnetic Materials 320, 2746-2751, (2008).

[6]. D. Samaras, J.G., Stavros M Panas and G. Litsardakis, Hexagonal ferrite particles for perpendicular recording prepared by ion exchange, IEEE Transactions on Magnetics 26, 18-20, (1990).

[7]. L.A. Garci, C., O.S. Rodri, Fernándeza, P.J. Reséndiz-Hernández, Study of $\mathrm{SrFe}_{12} \mathrm{O}_{19}$ synthesized by the sol-gel method, Journal of Alloys and Compounds 369, 182-184, (2004).

[8]. Gajbhiye, A.V.a.N.S., Magnetic properties of single-domain $\mathrm{SrFe}_{12} \mathrm{O}_{19}$ particles synthesized by citrate precursor technique, Journal of Applied Physics 83, (1998).

[9]. Tao Zhang, X.P., Jing Li, Yanting Yang, Jingcai Xu, Panfeng Wang, Dingfeng Jin, Hongxiao Jin, Bo Hong, Xinqing Wang, Hongliang Ge, Platelet-like hexagonal SrFe12019 particles: Hydrothermal synthesis and their orientation in a magnetic field, Journal of Magnetism and Magnetic Materials 412, 102-106, (2016).

[10]. Marghussian, V., Nano-glass ceramics: Processing, Properties and Applications, William Andrew, (2015).

[11]. Z. Ghiami, S.M.M., S. Alamolhoda, The Effect Of CTAB Surfactant Addition And Additional Sr On Phase Formation And Magnetic Properties Of Nanosized $\mathrm{SrFe}_{12} \mathrm{O}_{19}$ Synthesized Via Sol-Gel AutoCombustion Method, Iranian Journal of Materials Science and Engineering 12, 1-9, (2015).

[12]. S. M. Mirkazemi, S.A., Z. Ghiami, Microstructure and Magnetic Properties of
$\mathrm{SrFe}_{12} \mathrm{O}_{19}$ Nano-sized Powders Prepared by Sol-Gel Auto-combustion Method with

CTAB Surfactant, Journal of Superconductivity and Novel Magnetism, (2015).

[13]. G Elvin, I.P.P.P., Q.T. Bui, L.F. Barquin, Q.A. Pankhurst, A.V. Komarov and Y.G. Morozov, Self-propagating hightemperature synthesis of $\mathrm{SrFe}_{12} \mathrm{O}_{19}$ from reactions of strontium superoxide, iron metal and iron oxide powder, Journal of Materials Science Letters 16, 1237-1239, (1997).

[14]. Jiye Fang, J.W., Leong-Ming Gan, SerChoon Ng, Jung Ding, Xiangyuan Liu, Fine Strontium Ferrite Powders from an Ethanol-Based Microemulsion, Journal of the American Ceramic Society 83, 10491055, (2000).

[15]. Ebrahim Roohani, H.A., Reza Sarhaddi, Saeedeh Sudkhah and Ameneh Shabani, Effect of annealing temperature on structural and magnetic properties of strontium hexaferrite nanoparticles synthesized by sol gel auto-combustion method, International Journal of Modern Physics B 29, (2015).

[16]. Gholamreza Nabiyouni, A.A., Davood Ghanbari, Hamed Halakouie, $\mathrm{SrFe}_{12} \mathrm{O}_{19}$ ferrites and hard magnetic PVA nanocomposite: Investigation of magnetization, coecivity and remanence, Journal of Materials Science: Materials in Electronics 27, 4297, (2016). 